Bangladesh J. Pl. Breed. Genet., 26(2): 15-22, 2013

\title{
GENETIC VARIATION AND SELECTION CRITERIA FOR SEED YIELD RELATED TRAITS IN RAPE SEED (Brassica napus $\mathrm{L}$. .)
}

\author{
S. Parveen, M. H. Rashid and M. S. R. Bhuiyan \\ Department of Genetics and Plant Breeding \\ Sher-e-Bangla Agricultural University \\ Dhaka 1207, Bangladesh.
}

\begin{abstract}
The field experiment was conducted to estimate the genetic variability and correlation between yield contributing traits using 15 rape seed genotypes. The results indicated that the phenotypic variance for all the characters was considerably higher than the genotypic variance denoting little influence of environmental factors on their expression. Characters like 1000-seed weight $(12.39,14.10)$, days to $50 \%$ flowering $(18.36,18.77)$ and days to maturity $(4.63,5.06)$ showed low genotypic and phenotypic coefficient of variation. Moderate genotypic and phenotypic coefficient of variation was observed in number of primary branches per plant $(20.22,22.16)$, length of siliqua $(20.84,20.97)$, number of seeds per siliqua $(30.90,33.06)$, number of siliquae per plant $(49.34,49.81)$ and yield per plant $(34.36,39.98)$ and high genotypic (67.00) and phenotypic coefficient of variation (68.57) was observed for number of secondary branches per plant. Plant height $(85.98 \%, 30.89), 1000$ seed weight $(77.14 \%, 22.41)$, days to $50 \%$ flowering $(95.66 \%, 20.35)$ and days to maturity $(83.85 \%, 7.82)$ showed high heritability with low genetic advance which indicated the possibility of non-additive gene action. Number of primary branches per plant $(83.22 \%, 37.99,636.02)$, length of siliqua $(98.83 \%, 42.68,1084.42)$, number of seeds per siliqua $(87.40 \%, 59.52,424.22)$, number of siliqua per plant $(98.15 \%, 100.71,178.83)$ and yield per plant $(73.87 \%, 60.84,4539.97)$ showed high heritability with high genetic advance and high genetic advance in percentage of mean revealed the possibility of predominance of additive gene effects. Number of primary branches per plant had showed highly significant positive association with number of secondary branches per plant $(\mathrm{rg}=0.597, \mathrm{rp}=0.537)$ and yield per plant ( $\mathrm{rg}=0.43$ ). Days to $50 \%$ flowering showed significant positive association with seeds per siliqua ( $\mathrm{rg}=0.492 ; \mathrm{rp}=0.436), 1000$ seed weight $(\mathrm{rg}=0.486 ; \mathrm{rp}=0.472)$ and yield per plant $(\mathrm{rg}=0.438 ; \mathrm{rp}=0.379)$. Length of siliqua manifested highly significant positive association with siliqua per plant $(\mathrm{rg}=0.571 ; \mathrm{rp}=0.514)$ and significant negative association with yield per plant (-0.471) at genotypic level. Siliqua per plant had highly significant negative association at both genotypic and phenotypic level with yield per plant $(-0.697$; -0.525$)$ but 1000 seed weight had highly significant positive association with yield per plant both genotypic and phenotypic level $(0.893$; $0.814)$. The results of the path analysis revealed that 1000 seed weight $(0.766)$ had the maximum direct effect and the maximum negative direct effect was observed in seeds per siliqua (0.305). In summary, the results suggested that there were some yield related traits such as 1000 seed weight and days to $50 \%$ flowering could be selected and used in breeding program for increasing the grain yield of rapeseed.
\end{abstract}

Keywords: Genetic variability; germplasm; correlation coefficient; path coefficient; Brassica napus

\section{INTRODUCTION}

In Bangladesh mustard and rape seed is the first leading oil crops. Rape seed is the most important sources of edible oil in Bangladesh. There are three major cultivated 
species of Brassica in the country are B rapa, B. napus and B. juncea. Rape seed oil used for both industrial and culinary purpose. Extracted oil from mustard contains high protein $(37 \%)$ rich feed which is highly palatable to livestock. Now Bangladesh is facing shortage of edible oil. At present, production of oil seed is about 0.26 million tons, which covers only $30 \%$ of the domestic need. About $70 \%$ of requirement of oil has been imported every year by spending huge amount of foreign currency (BBS, 2011). In Bangladesh, the seed yield of mustard/rapeseed is about $740 \mathrm{~kg} / \mathrm{ha}$, which is very low in comparison to other developed countries (2400 kg/ha) (FAO, 2011). On the other hand, the area of cultivation of mustard in Bangladesh is lower due to rice based cropping system which is difficult to change.

Seed yield in rape is a complex and highly variable character and is being associated with a number of component characters. Yield improvement is the main goal in rape seed breeding. For this purpose, the first stage is to increase the understanding of genetical and morphological basis for seed yield and utilization of morphological traits as selection criteria in yield improvement program. Information related to genetic variability and character association is a prerequisite for initiating a successful breeding program aiming to develop high yielding and short duration varieties.

Correlation and path coefficient are used to assess the relative contribution of different components on yield (Sachan and Sharma, 1971 and Jatasra and Paroda, 1978). The understanding of association between component characters is of prime importance in developing an efficient breeding program. The correlation studies provide information about the relationship between the characters. The path coefficient analysis has been found to give more specific information on the direct and indirect influence of each of the component characters upon seed yield (Behl et al., 1992). Thus, the present study was undertaken to find out and establish suitable selection criteria for higher seed yield through study of genetic variability, heritability, genetic advance, correlation among different characters and the direct and indirect effect of these characters towards seed yield.

\section{MATERIALS AND METHODS}

The present research work was carried out in the experimental farm, Sher-eBangla Agricultural University (SAU), Dhaka during November 2005-March 2006. The location of the site is $23^{\circ} 74^{\prime} \mathrm{N}$ latitude and $90^{\circ} 35^{\prime} \mathrm{E}$ longitude with an elevation of 8.2 meter from sea level. The soil of the experimental plots was clay loam and the land was medium high with medium fertility level. Fourteen Brassica napus genotypes were used in this experiment. The experiment was set up in a RCBD design with three replications, following $30 \mathrm{~cm} \times 10 \mathrm{~cm}$ spacing. The unit plot size was $5 \mathrm{~m} \times 25 \mathrm{~m}$ and block to block distance was $1.5 \mathrm{~m}$. The plot was fertilized with $250,170,85,150,5 \mathrm{Kg} / \mathrm{ha}$ Urea, TSP, MOP, Gypsum and Borax respectively. Standard agronomic practices were carried out to raise healthy crop. Harvesting was done when $80 \%$ of the plants showed symptoms of maturity i.e. straw colour of siliquae, leaves, stem and desirable seed colour in the matured siliquae. Ten plants were selected at random from all genotypes in each plot and data were recorded on plant height $(\mathrm{cm})$, number of primary branches per plant, number of secondary branches per plant, length of siliqua $(\mathrm{cm})$, number of seeds per siliqua, number of siliquae per plant, days to $50 \%$ flowering, days to maturity, 1000 seed weight (g) and yield per plant $(\mathrm{g})$. The data were analyzed for different genetic components. Phenotypic and genotypic variance was estimated by the formula used by (Johnson et al., 1955). Heritability and genetic advance were measured using the formula given by (Singh and Chaudhary, 1985) and (Allard, 1960). Genotypic and phenotypic coefficient of variation was calculated by the formula of (Burton, 1952). Simple correlation 
coefficient was obtained using the formula suggested by (Singh and Chaudhary, 1985) and path co-efficient analysis was done following the method outlined by (Dewey and $\mathrm{Lu}, 1959)$.

\section{RESULTS AND DISCUSSION}

The results of analysis of variance (ANOVA) for all the traits under study are presented in Table 1. According to the table there was a significant difference among the genotypes for all the traits suggesting there were significant differences among the genotypes for all the characters.

Table 1. Analysis of variances of $\mathbf{1 0}$ important characters in respect of Brassica napus

\begin{tabular}{|c|c|c|c|c|c|c|}
\hline $\begin{array}{l}\text { Source of } \\
\text { variation }\end{array}$ & $\mathrm{df}$ & $\mathrm{PH}(\mathrm{cm})$ & PBP (no.) & SBP (no.) & LS (cm) & SS (no.) \\
\hline Replication & 2 & 143.91 & 0.22 & 0.05 & 0.01 & 7.29 \\
\hline Genotypes & 14 & $563.24 * *$ & $4.67 * *$ & $50159 * *$ & $2.03 * *$ & $59.11 * *$ \\
\hline Error & 28 & 29.03 & 0.29 & 0.08 & 0.01 & 2.71 \\
\hline $\mathrm{CV}(\%)$ & & 6.53 & 9.08 & 14.52 & 4.20 & 11.73 \\
\hline \multicolumn{7}{|l|}{ Contd. } \\
\hline $\begin{array}{l}\text { Source of } \\
\text { variation }\end{array}$ & $\mathrm{df}$ & SP (no.) & $1000 \mathrm{sw}(\mathrm{g})$ & $\mathrm{YP}(\mathrm{g})$ & DFF & $\overline{\mathrm{DM}}$ \\
\hline Replication & 2 & 29.13 & 0.07 & 0.01 & 5.49 & 9.36 \\
\hline Genotypes & 14 & $2330.80 * *$ & $0.36^{* * *}$ & $0.71 * *$ & $310.74 * *$ & $54.85^{* *}$ \\
\hline Error & 28 & 14.54 & 0.03 & 0.08 & 4.63 & 3.31 \\
\hline $\mathrm{CV}(\%)$ & & 6.77 & 6.75 & 20.49 & 3.91 & 4.03 \\
\hline
\end{tabular}

** Significant at $1 \%$ level of probability

$\mathrm{PH}=$ Plant height $(\mathrm{cm}), \mathrm{PBP}=$ Primary branches per plant, $\mathrm{SBP}=$ Secondary branches per plant, $\mathrm{LS}=$ Length of siliqua $(\mathrm{cm}), \mathrm{SS}=$ Seeds per siliqua, $\mathrm{SP}=$ Siliquae per plant, $1000 \mathrm{sw}=1000$ seed weight $(\mathrm{g}), \mathrm{YP}=\mathrm{Yield}$ per plant $(\mathrm{g}), \mathrm{DFF}=$ Days to $50 \%$ flowering, $\mathrm{DM}=$ Days to maturity.

It was found that the tallest plant of $105.10 \mathrm{~cm}$ was observed in BD-9100 while the shortest plant of $50.27 \mathrm{~cm}$ was in BD-9077 (Table 2). The maximum number of primary branches per plant (8.57) and number of secondary branches per plant (3.9) were recorded in BD-9104 and the minimum number of primary branches per plant 3.83 was in BD-9077. On the other hand, BD-9065 and BD-7810 had no secondary branches at all. Length of siliqua was observed the highest in BD-9106 $(5.90 \mathrm{~cm})$ and the lowest in BD-9078 $(2.93 \mathrm{~cm})$. Maximum number of seeds per siliqua (24.87) was recorded in BD9065 which was statistically identical with BD-9106 (22.51) and the minimum 9.22 was in BD-9100. The highest 1000 seed weight 3.21g was found in BD-7813 followed by BD-6949 (3.18g) and BD-7811 (3.14g) while the lowest 2.14g was found in BD-9104 which was statistically identical with BD-9078 $(2.17 \mathrm{~g})$.

Larger variations were observed for number of siliqua per plant in different genotypes. The highest number of siliquae per plant (97.20) was recorded for BD-9099 which was statistically identical with BD-9106 while the minimum number 23.10 was BD-7811 which was statistically identical with BD-7814 (24.36), BD-7813 (25.27) and BD-7812 (25.43). Early flowering (29.33 days) and early maturity (80.67 days) was observed in BD-9070 while late flowering was found in BD-7810 (64.33 days) followed by BD-7811 (64 days) and BD-7813 (63.67 days) respectively and late maturity 95 days was observed in BD-9100 and BD- 7811. The highest yield per plant $(2.13 \mathrm{~g})$ was recorded in BD-9078 and the lowest $(0.60 \mathrm{~g})$ was recorded in BD-7813 in Table 2. 
Table 2. Mean performance of 10 important characters in respect of Brassica napus

\begin{tabular}{|c|c|c|c|c|c|}
\hline Genotype & $\mathrm{PH}(\mathrm{cm})$ & PBP(no.) & SBP (no.) & LS (cm) & SS (no.) \\
\hline BD-9065 & $70.12 \mathrm{fg}$ & 4.23hi & $0.00 \mathrm{i}$ & $3.62 \mathrm{e}$ & $24.87 \mathrm{a}$ \\
\hline BD-9070 & $90.20 \mathrm{bcd}$ & $5.50 \mathrm{efg}$ & $3.13 b c$ & $3.29 \mathrm{f}$ & $14.21 \mathrm{bcd}$ \\
\hline BD-9076 & $74.07 \mathrm{ef}$ & $4.67 \mathrm{ghi}$ & $0.47 \mathrm{hi}$ & $3.66 \mathrm{e}$ & $15.30 \mathrm{bc}$ \\
\hline BD-9077 & $50.27 \mathrm{~h}$ & $3.83 \mathrm{i}$ & $2.27 \mathrm{ef}$ & $3.58 \mathrm{e}$ & $12.78 \mathrm{ccde}$ \\
\hline BD-9078 & $82.17 \mathrm{cde}$ & $5.10 \mathrm{fgh}$ & $0.50 \mathrm{hi}$ & $2.93 \mathrm{~g}$ & $16.30 \mathrm{~b}$ \\
\hline BD-9099 & $83.80 \mathrm{cde}$ & $5.47 \mathrm{~b}$ & $3.43 \mathrm{ab}$ & $3.69 \mathrm{e}$ & $13.66 \mathrm{bcd}$ \\
\hline BD-9100 & $105.10 \mathrm{a}$ & $6.23 \mathrm{cde}$ & $1.97 \mathrm{fg}$ & $4.09 \mathrm{~d}$ & $9.22 \mathrm{~g}$ \\
\hline BD-9104 & $82.58 \mathrm{cde}$ & $8.57 \mathrm{a}$ & $3.90 \mathrm{a}$ & $4.08 \mathrm{~d}$ & $13.16 \mathrm{~cd}$ \\
\hline BD-9106 & $84.93 \mathrm{~cd}$ & $7.03 b c$ & $3.53 \mathrm{ab}$ & $5.90 \mathrm{a}$ & $22.51 \mathrm{a}$ \\
\hline BD-6949 & $90.03 \mathrm{bcd}$ & $6.20 \mathrm{cde}$ & $1.70 \mathrm{~g}$ & $3.17 \mathrm{f}$ & $13.90 \mathrm{bcd}$ \\
\hline BD-7810 & $98.67 \mathrm{ab}$ & $6.800 \mathrm{bcd}$ & $0.00 \mathrm{i}$ & $3.60 \mathrm{e}$ & $11.27 \mathrm{defg}$ \\
\hline BD-7811 & $63.97 \mathrm{~g}$ & $5.67 \mathrm{efg}$ & $1.967 \mathrm{fg}$ & $4.56 c$ & 11.49defg \\
\hline BD-7812 & $81.53 \mathrm{de}$ & $6.10 \mathrm{cdef}$ & $2.80 \mathrm{~cd}$ & $4.43 c$ & $9.89 \mathrm{efg}$ \\
\hline BD-7813 & $88.03 \mathrm{~cd}$ & $5.87 \mathrm{def}$ & $0.93 \mathrm{~h}$ & $5.29 b$ & $12.32 \mathrm{cdef}$ \\
\hline BD-7814 & $92.20 b c$ & $6.53 \mathrm{bcd}$ & $2.53 \mathrm{de}$ & $3.19 \mathrm{f}$ & $9.57 \mathrm{fg}$ \\
\hline F-test & $* *$ & $* *$ & $* *$ & $* *$ & $* *$ \\
\hline LSD 0.05) & 9.01 & 0.91 & 0.47 & 0.15 & 2.75 \\
\hline $\mathrm{Sx} / \mathrm{sd}$ & 3.11 & 0.313 & 0.16 & 0.05 & 0.95 \\
\hline \multicolumn{6}{|l|}{ Contd. } \\
\hline Genotype & SP (no.) & $1000 \mathrm{sw}(\mathrm{g})$ & YP $(g)$ & DFF & DM \\
\hline BD-9065 & $35.33 \mathrm{f}$ & $2.27 \mathrm{ef}$ & $1.39 \mathrm{~cd}$ & $54.00 \mathrm{~d}$ & $90.33 \mathrm{bcd}$ \\
\hline BD-9070 & $85.00 \mathrm{~b}$ & $2.61 \mathrm{cde}$ & $1.99 \mathrm{ab}$ & $29.33 \mathrm{~g}$ & $80.67 \mathrm{~g}$ \\
\hline BD-9076 & $60.73 d$ & $2.42 \mathrm{def}$ & 1.06defg & $46.33 \mathrm{e}^{\circ}$ & $85.00 \mathrm{ef}$ \\
\hline BD-9077 & $55.37 d$ & $2.62 \mathrm{bcd}$ & $2.00 \mathrm{ab}$ & $48.00 \mathrm{e}$ & $83.67 f g$ \\
\hline BD-9078 & $86.40 \mathrm{~b}$ & $2.17 \mathrm{f}$ & $2.13 \mathrm{a}$ & $41.00 \mathrm{f}$ & $87.67 \mathrm{de}$ \\
\hline BD-9099 & $97.20 \mathrm{a}$ & $2.61 \mathrm{bcde}$ & $0.85 \mathrm{efg}$ & $59.33 \mathrm{c}$ & $89.67 \mathrm{bcd}$ \\
\hline BD-9100 & $42.10 \mathrm{e}$ & $2.44 \mathrm{cdef}$ & $1.35 \mathrm{cde}$ & $62.33 \mathrm{abc}$ & $95.00 \mathrm{a}$ \\
\hline BD-9104 & $36.60 \mathrm{ef}$ & $2.14 \mathrm{f}$ & $1.19 \mathrm{def}$ & $63.33 \mathrm{ab}$ & $91.67 \mathrm{abc}$ \\
\hline BD-9106 & $93.40 \mathrm{a}$ & $2.90 \mathrm{ab}$ & $1.54 \mathrm{bcd}$ & $59.67 \mathrm{bc}$ & $89.33 \mathrm{~cd}$ \\
\hline BD-6949 & $68.92 \mathrm{c}$ & $3.18 \mathrm{a}$ & $1.85 \mathrm{abc}$ & $53.00 \mathrm{~d}$ & $85.00 \mathrm{ef}$ \\
\hline BD-7810 & $85.47 \mathrm{~b}$ & $2.73 \mathrm{bcd}$ & $1.47 \mathrm{~cd}$ & $64.33 \mathrm{a}$ & $93.00 \mathrm{ab}$ \\
\hline BD-7811 & $23.10 \mathrm{~g}$ & $3.14 \mathrm{a}$ & $0.77 \mathrm{fg}$ & $64.00 \mathrm{a}$ & $95.00 \mathrm{a}$ \\
\hline BD-7812 & $25.43 \mathrm{~g}$ & $2.77 b c$ & $1.07 \mathrm{defg}$ & $54.33 d$ & $92.00 \mathrm{abc}$ \\
\hline BD-7813 & $25.27 \mathrm{~g}$ & $3.21 \mathrm{a}$ & $0.60 \mathrm{~g}$ & $63.67 \mathrm{a}$ & $93.00 \mathrm{ab}$ \\
\hline BD-7814 & $24.36 \mathrm{~g}$ & 2.58 bcde & $0.85 \mathrm{efg}$ & $62.67 \mathrm{abc}$ & $91.33 b c$ \\
\hline F-test & $* *$ & $* *$ & $* *$ & $* *$ & $* *$ \\
\hline LSD 0.05) & 6.38 & 0.30 & 0.46 & 3.6 & 3.04 \\
\hline $\mathrm{Sx} / \mathrm{sd}$ & 2.20 & 0.10 & 0.16 & 1.24 & 1.05 \\
\hline
\end{tabular}

In a column means having similar letter(s) or without letter is identical and those having dissimilar letter(s) differ significantly as per 0.05 level of probability. CV\% $=$ Percentage of co-efficient of variation, LSD = Least significant difference, $\mathrm{Sx} / \mathrm{sd}=$ Standard deviation

The phenotypic variance was considerably higher than the genotypic variance for all the characters studied indicating less environmental influence of these characters (Table 3). Deshmukh et al., (1986) also reported that phenotypic coefficient of variation was higher than the genotypic coefficient of variation. Least difference between phenotypic variance and genotypic variance were observed in number of primary branches per plant, number of secondary branches per plant, length of siliqua, number of seeds per siliqua, 1000 seed weight, days to maturity and yield per plant which indicated 
low environmental influence on this character which might be due to their genetic control.

Table 3. Estimation of some genetic parameters in respect of Brassica napus

\begin{tabular}{|c|c|c|c|c|c|}
\hline Parameters & $\mathrm{PH}(\mathrm{cm})$ & PBP (no.) & SBP (no.) & $\mathrm{LS}(\mathrm{cm})$ & SS (no.) \\
\hline$\sigma^{2} g$ & 178.07 & 1.46 & 1.69 & 0.67 & 18.80 \\
\hline$\sigma^{2} p$ & 207.10 & 1.75 & 1.77 & 0.68 & 21.51 \\
\hline GCV & 16.17 & 20.22 & 67.00 & 20.84 & 30.90 \\
\hline PCV & 17.44 & 22.16 & 68.57 & 20.97 & 33.06 \\
\hline $\mathrm{h}^{2} \mathrm{~b}(\%)$ & 85.98 & 83.22 & 95.49 & 98.83 & 87.40 \\
\hline GA & 30.89 & 37.99 & 134.87 & 42.68 & 59.52 \\
\hline GA $(\%)$ & 37.44 & 636.02 & 6944.99 & 1084.42 & 424.22 \\
\hline \multicolumn{6}{|l|}{ Contd. } \\
\hline Parameters & SP (no.) & $1000 \mathrm{sw}(\mathrm{g})$ & YP $(g)$ & DFF & $\mathrm{DM}$ \\
\hline$\sigma^{2} g$ & 772.09 & 0.11 & 0.21 & 102.04 & 17.18 \\
\hline$\sigma^{2} p$ & 786.62 & 0.14 & 0.29 & 106.67 & 20.49 \\
\hline GCV & 49.34 & 12.39 & 34.36 & 18.36 & 4.63 \\
\hline PCV & 49.81 & 14.10 & 39.98 & 18.77 & 5.06 \\
\hline $\mathrm{h}^{2} \mathrm{~b}(\%)$ & 98.15 & 77.14 & 73.87 & 95.66 & 83.85 \\
\hline GA & 100.71 & 22.41 & 60.84 & 20.35 & 7.82 \\
\hline GA $(\%)$ & 178.83 & 844.80 & 4539.97 & 36.99 & 8.74 \\
\hline
\end{tabular}

$\sigma^{2} \mathrm{~g}=$ Genotypic variance, $\sigma^{2} \mathrm{p}=$ Phenotypic variance, $\mathrm{GCV}=$ Genotypic coefficient of variation, $\mathrm{PCV}=$ Phenotypic coefficient of variation, $h^{2} b=$ Broad sense heritability, GA= Genetic advance, GA $(\%)=$ Genetic advance in percent of mean.

Relatively high phenotypic variation was observed in plant height $(207.10 \mathrm{~cm})$, days to $50 \%$ flowering (106.67days) and number of siliquae per plant (786.62) which indicated large environmental influence on these characters. Characters like 1000-seed weight $(12.39,14.10)$, days to $50 \%$ flowering $(18.36,18.77)$ and days to maturity $(4.63$, 5.06) showed low genotypic and phenotypic coefficient of variation indicated that the genotype has considerable variation for these traits. Moderate genotypic and phenotypic coefficient of variation was observed in number of primary branches per plant (20.22, $22.16)$, length of siliqua $(20.84,20.97)$, number of seeds per siliqua $(30.90,33.06)$, number of siliquae per plant $(49.34,49.81)$ and yield per plant $(34.36,39.98)$ which indicated moderate variability were present among the genotype for these characters. Number of secondary branches per plant showed high genotypic and phenotypic coefficient of variation (67.00) and (68.57) respectively indicated that the genotype were highly variable for this trait (Table 3 ).

Plant height $(85.98 \%, 30.89), 1000$ seed weight $(77.14 \%, 22.41)$, days to $50 \%$ flowering $(95.66 \%, 20.35)$ and days to maturity $(83.85 \%, 7.82)$ showed high heritability with low genetic advance which indicated the possibility of non-additive gene action. The high heritability was due to favorable influence of environment rather than genotype and selection for such traits might not be rewarding. Number of primary branches per plant $(83.22 \%, 37.99,636.02)$, length of siliqua $(98.83 \%, 42.68,1084.42)$, number of seeds per siliqua $(87.40 \%, 59.52,424.22)$, number of siliquae per plant $(98.15 \%, 100.71$, $178.83)$ and yield per plant $(73.87 \%, 60.84,4539.97)$ showed high heritability with high genetic advance and high genetic advance in percentage of mean revealed the possibility of predominance of additive gene effects and selection should lead to a fast genetic improvement of the material. 
Table 4. Correlation co-efficient among different characters of the Brassica napus

\begin{tabular}{|c|c|c|c|c|c|c|c|c|c|c|}
\hline Characters & Correlation & PBP & SBP & DFF & $\mathrm{DM}$ & LS & SS & SP & $1000 \mathrm{sw}$ & $\mathrm{YP}$ \\
\hline \multirow[t]{2}{*}{$\mathrm{PH}$} & $\mathrm{r}_{\mathrm{g}}$ & $0.599 * *$ & 0.033 & -0.014 & -0.301 & 0.188 & 0.0001 & -0.114 & 0.205 & 0.308 \\
\hline & $r_{p}$ & $0.539 * *$ & 0.322 & -0.002 & -0.264 & 0.185 & 0.030 & -0.045 & 0.193 & 0.245 \\
\hline \multirow[t]{2}{*}{ PBP } & $r_{g}$ & & $0.597 * *$ & 0.272 & -0.239 & 0.137 & 0.025 & -0.359 & 0.543 & $0.43^{*}$ \\
\hline & $r_{p}$ & & $0.537 * *$ & 0.241 & -0.256 & 0.119 & 0.012 & -0.289 & 0.492 & 0.349 \\
\hline \multirow[t]{2}{*}{ SBP } & $r_{g}$ & & & 0.277 & -0.175 & 0.061 & 0.041 & -0.098 & 0.056 & -0.109 \\
\hline & $r_{p}$ & & & 0.269 & -0.156 & 0.059 & 0.045 & -0.050 & 0.050 & -0.132 \\
\hline \multirow[t]{2}{*}{ DFF } & $r_{g}$ & & & & 0.169 & -0.186 & $0.492 *$ & -0.062 & $0.486^{*}$ & $0.438 *$ \\
\hline & $r_{p}$ & & & & 0.166 & -0.186 & $0.436^{*}$ & -0.392 & $0.472 *$ & 0.379 \\
\hline \multirow[t]{2}{*}{$\mathrm{DM}$} & $r_{g}$ & & & & & 0.318 & -0.223 & 0.294 & -0.240 & -0.235 \\
\hline & $r_{p}$ & & & & & 0.319 & -0.194 & 0.276 & -0.235 & -0.210 \\
\hline \multirow[t]{2}{*}{ LS } & $r_{g}$ & & & & & & -0.118 & $0.571 * *$ & -0.416 & $-0.471^{*}$ \\
\hline & $\mathrm{r}_{\mathrm{p}}$ & & & & & & -0.109 & $0.514 * *$ & -0.401 & -0.410 \\
\hline \multirow[t]{2}{*}{ SS } & $r_{g}$ & & & & & & & -0.363 & 0.296 & 0.111 \\
\hline & $r_{p}$ & & & & & & & -0.140 & 0.272 & 0.117 \\
\hline \multirow[t]{2}{*}{ SP } & $r_{g}$ & & & & & & & & -0.721 & $-0.697 * *$ \\
\hline & $r_{p}$ & & & & & & & & $-0.61 * *$ & $-0.525 * *$ \\
\hline \multirow[t]{2}{*}{$1000 \mathrm{sw}$} & $r_{g}$ & & & & & & & & & $0.893 * *$ \\
\hline & $r_{p}$ & & & & & & & & & $0.844^{* *}$ \\
\hline
\end{tabular}

**, Significant at the 0.01 level of probability *, Significant at the 0.05 level of probability

Here, $\mathrm{PH}=$ Plant height $(\mathrm{cm}), \mathrm{PBP}=$ Primary branches per plant, $\mathrm{SBP}=$ Secondary branches per plant, $\mathrm{LS}=\mathrm{Length}$ of siliqua $(\mathrm{cm}), \mathrm{SS}=\mathrm{Seeds}$ per siliqua, $\mathrm{SP}=\mathrm{Siliquae}$ per plant, $1000 \mathrm{sw}=1000$ seed weight $(\mathrm{g}), \mathrm{YP}=$ Yield per plant (g), DFF= Days to $50 \%$ flowering, DM= Days to maturity 
Plant height showed highly significant positive association with primary branches per plant both genotypic and phenotypic level. Singh et al., (1987) found similar result. The result revealed that the tallest plant initiated with an increase of number of primary branches per plant. On the other hand, plant height had non significant negative association with days to $50 \%$ flowering, days to maturity as well as siliquae per plant. Positive correlation of plant height with number of seeds per siliqua, number of siliqua per plant and negative correlation with 1000 seed weight were reported by Chaudhury et al., (1987). This is partial agreement with my present finding. Number of primary branches per plant had showed significant positive association with number of secondary branches per plant $\left(\mathrm{rg}=0.597^{* *}, \mathrm{rp}=0.537^{* *}\right)$ and yield per plant $(\mathrm{rg}=0.43 * *)$. On the other hand, it had non significant negative association with days to maturity $(\mathrm{rg}=-0.239 ; \mathrm{rp}=-0.256)$ and siliqua per plant $(\mathrm{rg}=-0.359 ; \mathrm{rp}=-0.289)$. This result is disagreement with Singh et al. (1969) who got negative association between number of primary and secondary branches/plant. Number of secondary branches per plant had non significant negative association both genotypic and phenotypic level with days to maturity $(-0.175 ;-0.56)$, siliqua per plant $(-0.098 ;-0.05)$ and yield per plant ($0.109 ;-0.132)$. Days to $50 \%$ flowering showed significant positive association with seeds per siliqua $\left(\mathrm{rg}=0.492^{*} ; \mathrm{rp}=0.436^{*}\right), 1000$ seed weight $\left(\mathrm{rg}=0.486^{*} ; \mathrm{rp}=0.472^{*}\right)$ and yield per plant $\left(\mathrm{rg}=0.438^{*} ; \mathrm{rp}=0.379\right)$ indicated that as the days to $50 \%$ flowering increases, the number of seeds per siliqua, 1000 seed weight and yield per plant would increase. Days to maturity had non significant negative association with seeds per siliqua $(-0.223 ;-0.104), 1000$ seed weight $(-0.240 ;-0.235)$ and yield per plant $(-0.235 ;-0.210)$ both genotypic and phenotypic level. Length of siliqua manifested highly significant positive association with siliqua per plant $\left(\mathrm{rg}=0.571^{* *} ; \mathrm{rp}=0.514 * *\right)$ indicated that as the length of siliqua increases, the number of siliqua per plant increases. On the other hand, length of siliqua had significant negative association with yield per plant $\left(-0.471^{*}\right)$ at genotypic level indicated that as the length of siliqua increases, it will decrease the yield per plant. Seeds per siliqua had non significant negative association with siliqua per plant $(\mathrm{rg}=-0.363 ; \mathrm{rp}=-0.140)$. Siliqua per plant had highly significant negative association at both genotypic and phenotypic level with yield per plant $\left(-0.697^{* *} ;-0.525^{* *}\right)$ but highly significant negative association with 1000 seed weight at phenotypic level $(-0.61 * *)$ indicated that number of siliqua per plant increases, the yield per plant and 1000 seed weight would decrease. 1000 seed weight had highly significant positive association with yield per plant both genotypic and phenotypic level $\left(0.893^{* * ;} 0.814^{* *}\right)$ indicated that as the 1000 seed weight increases, the yield per plant would increase.

Table 5. Partitioning of genotypic correlation with seed yield/plant into direct (bold) and indirect components of Brassica napus

\begin{tabular}{l|c|c|c|c|c|c|c|c|c|c}
\hline Character & PH & PBP & SBP & DFF & DM & LS & SS & SP & TSW & YP \\
\hline PH & $\mathbf{0 . 1 9 8}$ & -0.077 & -0.006 & -0.004 & 0.035 & -0.009 & -0.000 & 0.013 & 0.157 & 0.309 \\
PBP & 0.119 & $\mathbf{- 0 . 1 2 8}$ & -0.102 & 0.071 & 0.028 & -0.007 & -0.008 & 0.041 & 0.417 & 0.430 \\
SBP & 0.007 & -0.076 & $\mathbf{- 0 . 1 7 1}$ & 0.072 & 0.020 & -0.003 & -0.013 & 0.011 & 0.044 & -0.110 \\
DFF & -0.003 & -0.035 & -0.048 & $\mathbf{0 . 2 6 0}$ & -0.020 & 0.009 & -0.150 & 0.053 & 0.372 & 0.438 \\
DM & -0.060 & 0.031 & 0.030 & 0.044 & $\mathbf{- 0 . 1 1 6}$ & -0.015 & 0.068 & -0.033 & -0.184 & -0.235 \\
LS & 0.037 & -0.018 & -0.011 & -0.048 & -0.037 & $\mathbf{- 0 . 0 4 8}$ & 0.036 & -0.065 & -0.319 & -0.471 \\
SS & 0.000 & -0.003 & -0.007 & 0.128 & 0.026 & 0.006 & $\mathbf{- 0 . 3 0 5}$ & 0.041 & 0.227 & 0.112 \\
SP & -0.023 & 0.046 & 0.017 & -0.120 & -0.034 & -0.027 & 0.110 & $\mathbf{- 0 . 1 1 4}$ & -0.552 & -0.697 \\
TSW & 0.041 & -0.069 & -0.010 & 0.126 & 0.028 & 0.020 & -0.090 & 0.082 & $\mathbf{0 . 7 6 6}$ & 0.893 \\
R & & & & & & & & & & 0.287 \\
\hline
\end{tabular}

Here, $\mathrm{PH}=$ Plant height $(\mathrm{cm}), \mathrm{PBP}=$ Primary branches per plant, $\mathrm{SBP}=$ Secondary branches per plant, $\mathrm{LS}=$ Length of siliqua $(\mathrm{cm}), \mathrm{SS}=\mathrm{Seeds}$ per siliqua, $\mathrm{SP}=$ Siliqua per plant, $1000 \mathrm{sw}=1000$ seed weight $(\mathrm{g}), \mathrm{YP}=$ Yield per plant $(\mathrm{g}), \mathrm{DFF}=$ Days to $50 \%$ flowering, DM= Days to maturity. 
The results of the path analysis revealed that 1000 seed weight $(0.766)$ had the maximum direct effect followed by days to $50 \%$ flowering (0.26) and plant height (0.198). Maximum negative direct effect was observed for seeds per siliqua (0.305) followed by secondary branches per plant $(-0.171)$, primary branches per plant $(-0.128)$, days to maturity $(-0.116)$, siliquae per plant $(-0.114)$ and length of siliqua (-0.048). Siliqua per plant had negative direct effect as well as negative and highly significant genotypic correlation with yield (-0.697). The contributions of yield components like 1000 seed weight and days to $50 \%$ flowering were higher in the present study. Singh (1985) observed high positive direct effect on days to $50 \%$ flowering, plant height, primary branching, number of siliquae per plant, number of seeds per siliquae on yield. Varshney (1986) working with several strains of $B$. rapa found the negative direct effect of plant height, siliquae per plant, seeds per siliqua and 1000 seed weight on yield. The residual effect was 0.287 , indicated that about $72 \%$ of the variability was contributed by eight quantitative characters studied in path analysis. This low residual effect might be due to characters not studied, environmental factors, sampling error etc. The overall outcome of the present investigation depicts that a wide variation existed among the rape seed genotypes. Also there was correlation of different yield components with the yield of rape seed.

\section{REFERENCES}

Allard, R. W. 1960. Principles of Plant Breeding. John Wiley \& Sons. New York. p.36.

Behl, R. K., B. D. Chaudhary, R. P. Singh and D. P. Singh. 1992. Morpho-physiological determinants of oil yield in Brassica juncea under dryland conditions. The Indian Journal of Genetics and Plant Breeding. 52(3): 280-284.

BBS. 2011. Hand book of Agricultural Statistics. Bangladesh Bureau of Statistics. Ministry of Planning, Government of Peoples Republic of Bangladesh. p.14.

Burton, G. W. 1952. Quantitative inheritance in grasses. In Proceedings of $6^{\text {th }}$ International Grassland Congress. Ames, Iowa, USA. pp.277-283.

Chaudhury, B. D., S. K. Thakural, D. P. Singh and P. Singh. 1987. Genetics of yield and its components in Indian mustard. Narendra Deva Journal of Agricultural Research. 3(1): 37-43.

Deshmukh, S. N., M. S. Basu and P. S. Reddy. 1986. Genetic variability, character association and path coefficient of quantitative traits in Virginia bunch varieties of groundnut. Indian Journal of Agricultural Sciences. 56(12): 816-821

Dewey, D. R. and K. H. Lu. 1959. A correlation and path coefficient analysis of components of crested wheat grass seed production. Agronomy Journal. 51: 515-518.

FAO. 2011. FAO Production Year Book. Basic data unit, Statistic Division, FAO Rome, Italy.

Jatasra, D. S. and R. S. Paroda. 1978. Genetic divergence in wheat under different environmental conditions. Cereal Research Communications. 6: 307-317.

Johnson, H. W., H. F. Robinson and R. E. Comstock. 1955. Estimates of genetic and environmental variability in soyabeans. Agronomy Journal. 47: 314-318.

Sachan, K. S. and J. R. Sharma. 1971. Multivariate analysis of genetic divergence in tomato. Indian Journal of Genetics and Plant Breeding. 31(1): 86-93.

Singh, D. P., D. Singh, S. P. Singh, A. B. Singh and S. N. Mishra. 1969. Relationship among some important agronomic characters in Indian mustard. Indian Journal of Agricultural Sciences. 39: 362-365.

Singh, R. K. and B. D. Chaudhary. 1985. Biometrical methods in quantitative genetic analysis. Kalyani Publishers, New Delhi, India. p. 266.

Singh, R. P., B. P. Malik and D. P. Singh. 1987. Variation for morpho-physiological characters in genotypes of Indian mustard. Indian Journal of Agricultural Sciences. 57: 227-230.

Varshney, S. K., B. Rai and B. Singh. 1986. Component analysis of harvest index in Brassica oilseeds. Indian Journal of Agricultural Research. 20(3): 129-134. 